\title{
The emergency department experience of patients with early pregnancy complications: A qualitative study
}

\author{
Vanessa Rojas-Luengas, $\mathrm{MSc}^{*}$; Bianca Seaton, $\mathrm{MSc}, \mathrm{PhD}(\mathrm{c})^{\dagger}$; Katie Dainty (D, $\mathrm{PhD}^{\dagger \neq}$; \\ Shelley McLeod, MSc, PhD(c)*§; Catherine Varner, MD, MSc ${ }^{* \S}$
}

\begin{abstract}
CLINICIAN'S CAPSULE
What is known about the topic?

Women experiencing early pregnancy complications frequently seek care in the emergency department (ED), but little information exists about their ED experience.

What did this study ask?

What are the experiences and perceptions of care of women treated for early pregnancy complications?

What did this study find?

These findings highlight the ways in which ED care often does not meet patient expectations or needs.

Why does this study matter to clinicians?

The emotional complexity of this medical situation is often multi-faceted and can produce encounters that are distressing.
\end{abstract}

\section{ABSTRACT}

Objective: The purpose of this qualitative study was to explore the experiences and perceptions of care of women treated for early pregnancy complications in a Canadian emergency department (ED) and early pregnancy clinic (EPC).

Methods: We conducted a descriptive qualitative study to understand the perceptions, meanings, and perspectives of women of 18 years and older who presented to the ED or EPC of an urban, tertiary care hospital with early pregnancy complications or loss. Using a semi-structured interview guide, a 45- to 60-minute telephone interview was conducted by a trained qualitative interviewer at 4 to 6 weeks after the ED visit. All interviews were digitally recorded and transcribed verbatim for analysis. Data analysis occurred in conjunction with data collection in order to continuously monitor emerging themes and general areas for further exploration. Interviews were conducted until thematic saturation had occurred.
Results: Interviews were completed with 30 women between June and August 2018. Three key themes arose: disconnect of the ED's role in the provision of care, normalization of a chaotic healthcare experience, and finding connection through the institution's EPC.

Conclusions: Perspectives of women with early pregnancy complications highlight the ways in which ED care often does not meet the expectations or needs of patients and their families. The emotional complexity of this medical situation is often overlooked by ED staff and can produce encounters that are distressing. However, negative experiences were often mitigated by follow-up care in the institution's EPC.

\section{RÉSUMÉ}

Introduction: L'étude qualitative portait sur l'expérience vécue par des femmes traitées pour des complications en début de grossesse dans un service des urgences (SU) au Canada ou dans une clinique spécialisée dans la prise en charge des troubles du début de la grossesse, ainsi que sur leur impression des soins reçus.

Méthode: Il s'agit d'une étude qualitative et descriptive visant à connaître l'impression que des femmes âgées de 18 ans et plus avaient des soins reçus dans un SU d'un centre hospitalier de soins tertiaires situé en milieu urbain pour des complications en début de grossesse ou un avortement, ou dans une clinique spécialisée en la matière; à cet élément s'ajoutent la portée de l'expérience vécue et le point de vue des participantes. Des entretiens téléphoniques semi-directifs, d'une durée de 45 à 60 minutes ont été effectués de 4 à 6 semaines après la consultation au SU, à l'aide d'un guide, par une personne ayant reçu une formation en recherche qualitative. Les entretiens ont tous été enregistrés sous forme numérique et transcrits textuellement aux fins d'analyse. La collecte de données ainsi que l'analyse des donnés se sont déroulées en parallèle afin de permettre un suivi continu de l'émergence de

From the *Schwartz/Reisman Emergency Medicine Institute, Sinai Health System, Toronto, ON; †Department of Emergency Medicine, North York General Hospital, Toronto, ON; ¥Institute for Health Policy, Management and Evaluation, University of Toronto, ON §Department of Family and Community Medicine, University of Toronto, ON.

Correspondence to: Dr. Catherine Varner, Schwartz/Reisman Emergency Medicine Institute, Sinai Health System, Department of Family and Community Medicine, University of Toronto, 206-600 University Avenue, Toronto, ON M5G 1X5; Email: catherine.varner@ sinaihealthsystem.ca

(C) Canadian Association of Emergency Physicians

CJEM 2019;21(6):798-802

DOI 10.1017/cem.2019.398 
nouveaux thèmes ou d'éléments généraux nécessitant un examen approfondi. Les entretiens se sont poursuivis jusqu'à l'atteinte du point de saturation thématique.

Résultats: Trente femmes ont participé à l'étude, entre juin et août 2018. Trois grands thèmes se sont dégagés des entretiens, soit le manque d'empathie du personnel au SU, la normalisation d'une prestation chaotique des soins de santé et, en revanche, le sentiment de compréhension ressenti à la clinique spécialisée, rattachée à l'établissement.

Conclusions: Le point de vue des femmes ayant vécu des complications en début de grossesse met en lumière le fait que souvent la prestation des soins au SU ne répond pas aux besoins et aux attentes des patientes et de leur famille. La complexité de la charge émotive liée au problème médical est bien des fois négligée par le personnel au SU, ce qui peut donner lieu à des situations pénibles. Toutefois, I'expérience défavorable vécue par les femmes est souvent atténuée par le suivi assuré à la clinique spécialisée, rattachée à l'établissement.

Keywords: Emergency medicine, qualitative, early pregnancy, ectopic pregnancy, miscarriage

\section{INTRODUCTION}

Emergency department (ED) utilization during pregnancy varies between $21 \%$ and $49 \%$, with a higher frequency of return ED visits compared with non-pregnant ED patients. ${ }^{1-3}$ Although the proportion of visits related to early pregnancy complications, such as miscarriage, threatened loss, or ectopic pregnancy, has yet to be documented, Canadian EDs frequently care for these early pregnant patients, because most have not yet established care with an obstetrical care provider. ${ }^{4}$

A recent survey of Ontario EDs identified that fragmented care exists in Ontario hospitals without early pregnancy clinic (EPC) services, and reliance on EDs to provide ongoing follow-up for women experiencing complications of early pregnancy is high. ${ }^{5}$ The survey also revealed that many Ontario EDs lack the necessary psychological supports to address the emotional needs of women undergoing early pregnancy loss, with less than half having access to on-site counselling supports such as a social worker. Previous research has shown that EDs often fail to provide the compassionate care and emotional support women require during this distressing time. ${ }^{6-9}$ These results are worrisome because pregnancy loss can lead to depression, anxiety, and posttraumatic stress disorder, regardless of fetal age..$^{10,11}$

The objective of this qualitative study was to better understand the experiences and perceptions of care of women treated for early pregnancy complications in a Canadian ED and EPC with a view to informing areas for improvement.

\section{METHODS}

\section{Study design}

We conducted a descriptive qualitative study to understand the perceptions, meanings, and perspectives of women of 18 years and older who presented to the ED or EPC of an urban, tertiary care hospital with early pregnancy complications or loss. Complete details of the study design, methods, and analysis are included in Supplemental Appendix A. The study hospital has an EPC model whereby ED patients with early pregnancy complications deemed safe for discharge home are supposed to be referred for urgent, ongoing follow-up.

\section{Data collection}

Eligible patients in the ED or EPC were identified by a treating physician or nurse and then approached by a research coordinator, who verbally reviewed and distributed letters of information about the study. Patients who were interested in participating provided their written consent to be contacted 4 weeks after their initial ED visit to schedule an interview. Using a semi-structured interview guide (Supplemental Appendix B), a 45- to 60 -minute telephone interview was conducted by a trained qualitative interviewer at 4 to 6 weeks after the ED visit. All interviews were digitally recorded and transcribed verbatim for analysis. Research ethics board approval was obtained from Mount Sinai Hospital in Toronto, Ontario (18-0078-E).

\section{Data analysis}

Data analysis occurred in conjunction with data collection in order to continuously monitor emerging themes and general areas for further exploration. Interviews were conducted until thematic saturation had occurred. The data were analysed collaboratively by two qualitative researchers, a clinician, a clinical researcher, and a research student according to standard thematic analysis techniques. ${ }^{12}$ Data management was facilitated using NVivo software (version 11). 


\begin{tabular}{|c|c|c|}
\hline Theme & ID & Quote \\
\hline \multirow[t]{3}{*}{$\begin{array}{l}\text { Disconnect of the ED's role in the } \\
\text { provision of care }\end{array}$} & P15 & $\begin{array}{l}\text { "I already felt like I was wasting everybody's time... [hospital staff] pointing out that this is } \\
\text { happening and it's not an emergency... I'm following direction that my doctor gave me. I was } \\
\text { already feeling like I shouldn't have been there. Like I was wasting resources." }\end{array}$ \\
\hline & P02 & $\begin{array}{l}\text { "This is my first pregnancy, so I truly don't know a lot [...] what you should be feeling, or what's } \\
\text { normal. I guess it was considered light bleeding, but it was still shocking to see [...] That's } \\
\text { why I went into the emergency room[...] there was a component of it that felt like I was } \\
\text { wasting his time [...] But I was scared [...] I think I kept apologizing to the physician, trying to } \\
\text { get reassurance that other people do this, that I'm not crazy, that it wasn't a complete } \\
\text { overreaction." }\end{array}$ \\
\hline & P29 & $\begin{array}{l}\text { "To be honest, [at the ED] I just felt like I was really rushed. And felt like [the doctor] didn't care } \\
\text { about anything. There was no emotional support." }\end{array}$ \\
\hline \multirow[t]{3}{*}{$\begin{array}{l}\text { Normalization of a chaotic healthcare } \\
\text { experience }\end{array}$} & P06 & $\begin{array}{l}\text { "I was apparently one of five or six ectopic pregnancies that [went] down that evening. We } \\
\text { were all waiting together in the rapid assessment zone. And there was a woman in there that } \\
\text { had a newborn baby. And that was hard. I know it's difficult in any space, but for someone } \\
\text { who's now having to terminate a pregnancy sitting next to someone who's just given birth to } \\
\text { a baby." }\end{array}$ \\
\hline & P01 & $\begin{array}{l}\text { "Then, [the] resident comes, I get put back in a room ... Then, I'm put back in the seating area } \\
\text {... Being thrown back and forth between sitting with my elbows rubbing up against a } \\
\text { stranger while I bawl my eyes out, to then have to revisit the conversation all over again. I } \\
\text { understand the concept of it, and that it makes the emerg flow better ... That, I didn't like, but } \\
\text { fine. I sucked it up. It is what it is. I dealt with it." }\end{array}$ \\
\hline & P07 & $\begin{array}{l}\text { "I walked [into the ED for a second time] [in] a lot of pain [...] I was covered in blood, my pants } \\
\text { were covered in blood and I couldn't walk [...] I had to sit [at registration] and answer all } \\
\text { questions again [...] like my age, [...] my last period [...] That part was really difficult." }\end{array}$ \\
\hline \multirow[t]{2}{*}{$\begin{array}{l}\text { Finding connection through the early } \\
\text { pregnancy clinic }\end{array}$} & P01 & $\begin{array}{l}\text { "She was amazing. She was the most informative person I had dealt with. She gave me clarity. I } \\
\text { felt comfort. If it wasn't for her, I don't even know. Just the fact that she was able to } \\
\text { sympathize with me and provide simple information that would have been nice to have in the } \\
\text { beginning." }\end{array}$ \\
\hline & P16 & $\begin{array}{l}\text { "I felt more comfortable that I was under the care of someone and not just kind of lost as a } \\
\text { patient in the ER." }\end{array}$ \\
\hline
\end{tabular}

\section{RESULTS}

After approaching 56 potential participants, interviews were completed with 30 women between June and August 2018. Our sample included a diverse group of women between the ages of 25 and 45, most of whom had no previous history of miscarriage, and were between 4 and 13 weeks pregnant at the time of their ED visit (Supplemental Appendix C). Three main thematic concepts emerged (Table 1):

\section{Theme 1: Disconnect regarding the ED's role in the provision of care}

Participants frequently reported being told by their family physician, infertility specialist, obstetrician, or other healthcare professional to go to the ED for spotting, cramping, bleeding, or pain. However, upon arriving to the ED, they were made to feel as though their symptoms did not warrant ED care or attention. Many participants used terms like "I felt I was wasting their time," and participants often experienced actual shaming behaviour from hospital staff.

One contrary case was described by a patient with symptoms suggestive of ruptured ectopic pregnancy, who reported positive perceptions of their care, particularly around the sense of urgency of their ED assessment and treatment (P03). However, once ectopic pregnancy rupture was excluded, the patient noted that urgency and attention towards her care was diminished.

\section{Theme 2: Normalization of a chaotic healthcare experience}

Women described lengthy hospital encounters involving multiple consultations with various healthcare providers, 
numerous procedures, and long wait times in a crowded ED environment. Surprisingly, patients felt the waits were expected in a high volume obstetrical centre, and given the hospital's reputation, assumed this was normal and the ED care would be excellent. However, a number of women reported that despite being seen by multiple clinicians, they were often not informed about the side effects, success rate, and next steps regarding treatments administered in the ED for ectopic pregnancy and miscarriage. In addition, very few participants problematized what was substandard care, including one participant who had a missed ectopic pregnancy (P16) and another participant in whom follow-up was not arranged following methotrexate administration for ectopic pregnancy (P01).

\section{Theme 3: Finding connection through the early pregnancy clinic}

Most patients interviewed received ongoing follow-up care in the institution's EPC at 12-72 hours after their ED visit. Many women described their tremendous appreciation of the compassionate care provided in the nurse-led clinic. After their EPC visit, participants said they left with a better understanding of their clinical situation and a general sense of being "cared for." In particular, participants appreciated the emotional support provided during their clinic interactions and reported that these supports were integral to their recovery.

On the contrary, when EPC follow-up had not occurred, patients' beliefs around their pregnancy outcomes were not accurate. For example, two women strongly believed that an intervention could have been done in the ED to prevent their loss, when, in fact, early pregnancy loss is rarely preventable. Neither had follow-up in the EPC, as participant P006 was greater than 12 weeks gestational age and follow-up was not arranged for participant P012.

\section{DISCUSSION}

This study describes the experiences and perceptions of care of women treated for early pregnancy complications in a Canadian ED and EPC. Our findings identified several areas of disconnect throughout the healthcare encounter and highlight the potential for comprehensive, urgent pregnancy-specific follow-up as a means to mitigate the negative experiences of early pregnancy complications and loss.

In this study, women often came to the ED because they felt or were told something was "wrong" with their pregnancy. Similar to previous studies, ${ }^{9}$ patients sought answers, reassurance, care, and expected to receive support and validation in the ED. Not being prioritized in the ED while experiencing the stress and discomfort of early pregnancy complications left women feeling that time was wasted when something could have been done. Previous qualitative studies of patients with early pregnancy complications report that ED staff lack empathy, compassion, and social supports, potentially contributing to adverse psychological outcomes. ${ }^{6-11}$ The highly technical clinical care by ED providers to exclude dangerous entities was often at odds with patients' expectations for more comprehensive, empathetic, supportive care.

Surprisingly, very few patients problematized the often substandard ED care in this study. The prolonged hours spent during these visits were often justified and minimized by the participants, many of whom were unaware that subsequent ED visits could have been prevented with appropriate discharge information and follow-up arrangement by the index ED provider. Similar to previous qualitative studies, participants suggested improved communication for what should be expected during the ED visit, as well as after discharge from the ED, including specific instructions of when to return is needed. ${ }^{9}$

Based on the experiences of women in this study, the EPC model appears better equipped to provide a more tailored, patient-centred experience and greater understanding of early pregnancy complications and loss. EPCs have previously been shown to provide timely, cost-effective care and improved quality of care and patient satisfaction. ${ }^{13,14}$ Urgent follow-up in an EPC does not absolve ED providers from improving care for this and other distressed and grieving patient populations. However, the EPC does provide a buffer for the adverse psychological impact of the chaotic ED environment and offers a safety net for patients when ED care is insufficient or does not meet patient expectations. In areas where an EPC model is not possible, training of nursing or other health professional staff could provide similar support.

This study is not without limitations. This study was performed at a single, urban tertiary care centre with access to an EPC. Patient experiences may not be generalizable to all Canadian hospitals. 


\section{CONCLUSIONS}

Complications in early pregnancy that require women to attend an ED create untenable situations for both the women experiencing them and the EDs caring for them. The emotional complexity of this medical situation is often multi-faceted and can produce encounters that are distressing. However, the EPC model shows promise in mitigating some of these issues and warrants further study.

Supplementary material: The supplementary material for this article can be found at https://doi.org/10.1017/cem.2019.398.

Acknowledgements: This study would not have been possible without the support of Dr. Kristin Blakely-Kozman.

Competing interests: None declared.

\section{REFERENCES}

1. Cunningham S, Magriples U, Thomas J, et al. Association between maternal comorbidities and emergency department use among a national sample of commercially insured pregnant women. Acad Emerg Med 2017;24:940-7.

2. Magriples U, Kershaw TS, Rising SS, et al. Prenatal health care beyond the obstetrics service: utilization and predictors of unscheduled care. Am 7 Obstet Gynecol 2008;198:75.e1-7.

3. Malik S, Kothari C, MacCallum C, et al. Emergency department use in the perinatal period: an opportunity for early intervention. Ann Emerg Med 2017;70(6):835-9.

4. Better Outcomes Registry and Network Ontario (BORN). Perinatal health reports 2009-2010; 2011.
Available at: https://www.bornontario.ca/en/resources/ reports/lhin-regional-reports/ (accessed May 22, 2019).

5. Glicksman R, McLeod S, Thomas J, Varner C. Services for emergency department patients experiencing early pregnancy complications: a survey of Ontario hospitals. CFEM 2019; epub, doi:10.1017/cem.2019.402.

6. Meaney S, Corcoran P, Spillane N, O'Donoghue K. Experience of miscarriage: an interpretative phenomenological analysis. BM7 Open 2017;7(3):e011382.

7. Smith L, Frost J, Levitas R, Bradley H, Garcia J. Women's experiences of three early miscarriage management options: a qualitative study. Br 7 Gen Pract 2006;56(524):198-205.

8. MacWilliams K, Hughes J, Aston M, Field S, Moffatt F. Understanding the experience of miscarriage in the emergency department. 7 Emerg Nurs 2016;42(6):504-12.

9. Van den Berg MMJ, Dancet EAF, Erlikh F, et al. Patientcentered early pregnancy care: a systematic review of quantitative and qualitative studies on the perspective of women and their partners. Hum Reprod Update 2018;24(1):106-18.

10. Lok I, Yip A, Lee D, Sahota D, Chung T. A 1-year longitudinal study of psychological morbidity after miscarriage. Fertil Steril 2010;93(6):1966-75.

11. Marcinko V, Marcink D, Dordevic V, Oreskovic S. Anxiety and depression in pregnant women with previous history of spontaneous abortion. Coll Antropol 2011;35(Suppl 1):225-8.

12. Boyatis R. Transforming qualitative information: thematic analysis and code development. Thousand Oaks, CA: Sage; 1998.

13. Bigrigg MA, Read MD. Management of women referred to early pregnancy assessment unit: care and cost effectiveness. BM7 1991;302(6776):577-9.

14. Wendt K, Crilly J, May C, Bates K, Saxena R. An outcomes evaluation of an emergency department early pregnancy assessment service and early pregnancy assessment protocol. Emerg Med J 2014;31(e1):e50-4. 